\title{
Comparative Study Regarding some Reproductive Parameters and Birth Weights in Rusty Tsigaia Breed and in Crossing with Blanc du Massif Central
}

\author{
Ioan PAŞCA ${ }^{1}$, Adrian CÎMPEAN ${ }^{1}$, Dana PUSTA ${ }^{1}$, Attila MÁTÉ ${ }^{2}$, Mihai Marian BORZAN ${ }^{1 *}$ \\ ${ }^{1}$ Department of Animal Productions and Food Safety, USAMV Cluj, Romania \\ ${ }^{2} S C D A$ Turda, Romania \\ *Corresponding author: mihai_borzan@yahoo.com
}

Bulletin UASVM Veterinary Medicine 73(1) / 2016,

Print ISSN 1843-5270; Electronic ISSN 1843-5378

DOI:10.15835/buasvmcn-vm: 11640

\begin{abstract}
The crossings of the Rusty Tsigaia breed with a meat breed, like Blanc du Massif Central, will increase the carcass characteristics of the crossed lambs, so this will correspond to the market demands. The aim of the study was to compare some reproductive parameters between two batches of 50 Rusty Tsigaia ewes (50 of pure breed and 50 crossed with BMC) for fertility, fecundity and prolificacy rate. Also the birth weight of the lambs was evaluated. The research was conducted on a selected flock of 100 Rusty Tsigaia sheep that were divided in two batches: 50 ewes were mated with Rusty Tsigaia rams and 50 ewes were mated with Blanc du Massif Central ram. After lambing, the birth weight was evaluated between the Rusty Tsigaia lambs and the lambs resulted from the crossing with BMC ram. The results were similar between the two batches concerning the conceiving, prolificacy and fecundity rate (Rusty Tsigaia rams x Rusty Tsigaia ewes and Blanc du Massif Central rams and Rusty Tsigaia ewes). Concerning the birth weights, the results showed a significant difference between the pure breed lambs and the crossed lambs, the crossed lambs having a superior weight.
\end{abstract}

Keywords: birth weight, Blanc du Massif Central, fecundity, fertility, prolificacy rate, Rusty Tsigaia

\section{INTRODUCTION}

The Rusty Tsigaia is a breed of sheep that is elevated in pure genetic stock at SCDA Turda. The demand for this breed on the market is low, compared with the high productivity of other foreign breeds. The crossings with a meat breed, like Blanc du Massif Central, will increase the carcass characteristics of the crossed lambs (to a superior class in the EUROP carcass classification), so this will correspond to the market demands, but this won't change the pure genetic of the Rusty Tsigaia because the resulting F1 crossed lambs are made for slaughtering (David, 2006; Pascal et al., 2014; Pascal et al., 2009; FAO Statistical Yearbook, 2014). Similar research for obtaining F1 lambs was documented in our country (Pascal and Nechifor, 2014; Băcilă et al., 2014), but not with the Blanc du Massif Central breed, this study being the first original study regarding the crossing of Rusty Tsigaia with the French meat breed.

The aim of the study was to compare some reproductive parameters between two batches of 50 Rusty Tsigaia ewes (50 of pure breed and 50 crossed with BMC) to assess the fertility, the fecundity and prolificacy rate. Also the birth weight of the lambs was evaluated.

Hypothesis: $\mathrm{H}_{0}$ : birth weight of the lambs in the experimental batch (Rusty Tsigaia ewes and Blanc du Massif Central ram) is the same as the weight of the control batch (Rusty Tsigaia ewes bred with Rusty Tsigaia ram). $\mathrm{H}_{1}$ : birth weight of the lambs in the experimental Batch (Rusty Tsigaia ewes and Blanc du Massif Central ram) is different 
that the weight of the control batch (Rusty Tsigaia ewes bred with Rusty Tsigaia ram).

\section{MATERIALS AND METHODS}

The study was conducted on two batches of 50 Rusty Tsigaia ewes each, both belonging to SCDA Turda. The experimental batch (50 Rusty Tsigaia ewes) was mated with one Blanc du Massif Central ram by selective breeding, after the ewes were hormonally synchronized. The control batch (50 Rusty Tsigaia ewes) was mated with one Rusty Tsigaia ram, after the estrus was synchronized in the same way as described for the experimental batch. The ewes were synchronized so that the rams would have mated 10 ewes per day, with a day break between the breeding, through a guided breeding, under supervision and recording each breeding. So, each rams had to breed 10 ewes per day, with one day break between breeding.

All the ewes included in the study were purebred Rusty Tsigaia, clinical healthy, aged between 1 and 4 years old, without any known reproductive pathology. The ewes found to present pathology, known reproductive pathology, less than one year and over 4 years old, pregnant, or not purebred, they were excluded from the study and replaced with ewes that corresponded to the described criteria, so that the 100 ewes included in the study were homogenous. The ewes selected in the study were separated from the rest of the flock for two months before the beginning of the study and they received a supplementary diet in order to prepare them for the breeding season.

The ewes from experimental and control batch were hormonally synchronized using progesterone - vaginal sponges (Chronogest ${ }^{\circledR} C R$, produced by MSD Animal Health) and eCG (Folligon - MSD Animal Health), according to protocols found in literature (Noakes et al., 2009; Padeanu, 2011; O'Callaghan, 1999; Harseign, 1992). The sponges were introduced with a special applicator and left in place for 14 days. At the removal of the cronolone impregnated sponges, 500 UI of eCG (Folligon) were administered intramuscular. After removal of the sponge the estrus signs began to show at 36 to 66 hours later. For the efficacy of the breeding and to avoid overloading the rams, the ewes were synchronized in 5 groups of 20 ewes in order to be bred by the two rams (10 ewes/ram/day). The 5 groups were synchronized progressively to assure a day break between the breeding sessions. The two batches were bred naturally with the rams.

At 50 and 60 days after breeding, the pregnancy diagnosis was performed using a microconvex $5 \mathrm{MHz}$ trans abdominal probe on a portable ultrasound (Mindray DP-2200 Vet). The ultrasound examination was repeated at 130-140 days after mating.

The reproduction parameters evaluated were calculated after the following formulas (Ptaszynska, 2009):

$$
\begin{aligned}
& \text { fecundity }=\frac{\text { number of lambs born (dead and alive) }}{\text { number of ewes exposed to the ram or } \mathrm{AI}} X 100 \\
& \text { fertility }=\frac{\text { numer of ewes lambing }}{\text { number of ewes exposed to the ram or AI }} X 100 \\
& \text { prolificac } y=\frac{\text { number of lambs born (dead and alive) }}{\text { number of ewes lambing }} X 100
\end{aligned}
$$

The weight and sex of the lambs was recorded at birth.

The data obtained were statistically evaluated with Microsoft Excel using the ANOVA and T test to evaluate statistical differences in birth weights of the lambs.

Concerning the birth weight of the born lambs, we wanted to see if there are differences between the lambs born in the control batch and in the experimental batch.

\section{RESULTS AND DISCUSSION}

After the ultrasound examination performed at 50-60 days after the breeding the following data were obtained:

In the experimental batch, out of 50 ewes mated with Blanc du Massif Central ram, 47 ewes (94\%) were pregnant. In the control batch, out of 50 ewes mated with Rusty Tsigaia ram, 46 were pregnant (92\%).

The second ultrasound, performed between 130-140 days, revealed that in the experimental batch 43 ewes were pregnant, and in the control batch only 44 ewes maintained pregnancy.

Concerning the pregnancy diagnosis after the ultrasound examination at 50-60 days and the number of lambing ewes, we recorded a difference, but the recorded data that we obtained are considered normal for an extensive farming system like the farm were the study was conducted (Ptaszynska, 2009). The second ultrasound examination performed between 130140 days compared with the number of lambed 
ewes revealed the accuracy of the pregnancy diagnosis. The difference recorded between the two ultrasound examinations was recorded as pregnancy lost.

In the experimental batch (Rusty Tsigaia ewes bred with Blanc du Massif Central ram) 43 ewes gave birth to 45 lambs, 2 ewes presented 2lambs at birth.

In the control batch (Rusty Tsigaia ewes bred with Rusty Tsigaia ram) 44 sheep lambed out of the 50 bred ewes. 47 lambs were born, 3 ewes had twins.

No dystocia were recorded.

After evaluating the reproductive parameters for fertility, fecundity and prolificacy, we registered the following results:

The fertility rate showed that both groups had similar results, more than $85 \%$, with higher values in the ewes bred with the Rusty Tsigaia ram, but also the fecundity rate (more than 90\% in both groups) was higher in the control batch. The same situation was found at prolificacy, where the values recorded were $104 \%$ in the batch bred with Blanc du Massif Central ram and 106\% in the control batch.

The reproduction analyzed parameters were superior in the control group, but there are many factors that can affect the ewes' reproduction, not only the ram (Rosa, 2003; Groza, 2006; Noakes, 2009; Ptaszynska, 2009).

The share of gender in the lambs revealed that more males were born, even if in the control group more than two thirds of the batch were females (Figure 1).

Gender analysis revealed that in the experimental batch more males were born, fact that can be further investigated to evaluate the male rate in the crossings or per ram.

In the control batch (Rusty Tsigaia ewes X with Rusty Tsigaia ram) we recorded the lower birth weights of lambs with an average of $3,5934 \pm 0,1739$ $\mathrm{Kg}$, compared with the average of $5,2159 \pm 0,347 \mathrm{Kg}$ recorded in the experimental batch (Rusty Tsigaia ewes X Blanc du Massif Central ram) (Tab. 1).

The Anova test showed that the $\mathrm{H}_{0}$ hypothesis is rejected and $\mathrm{H}_{1}$ hypothesis is accepted, because

Tab. 1. The reproductive parameters in the two batches

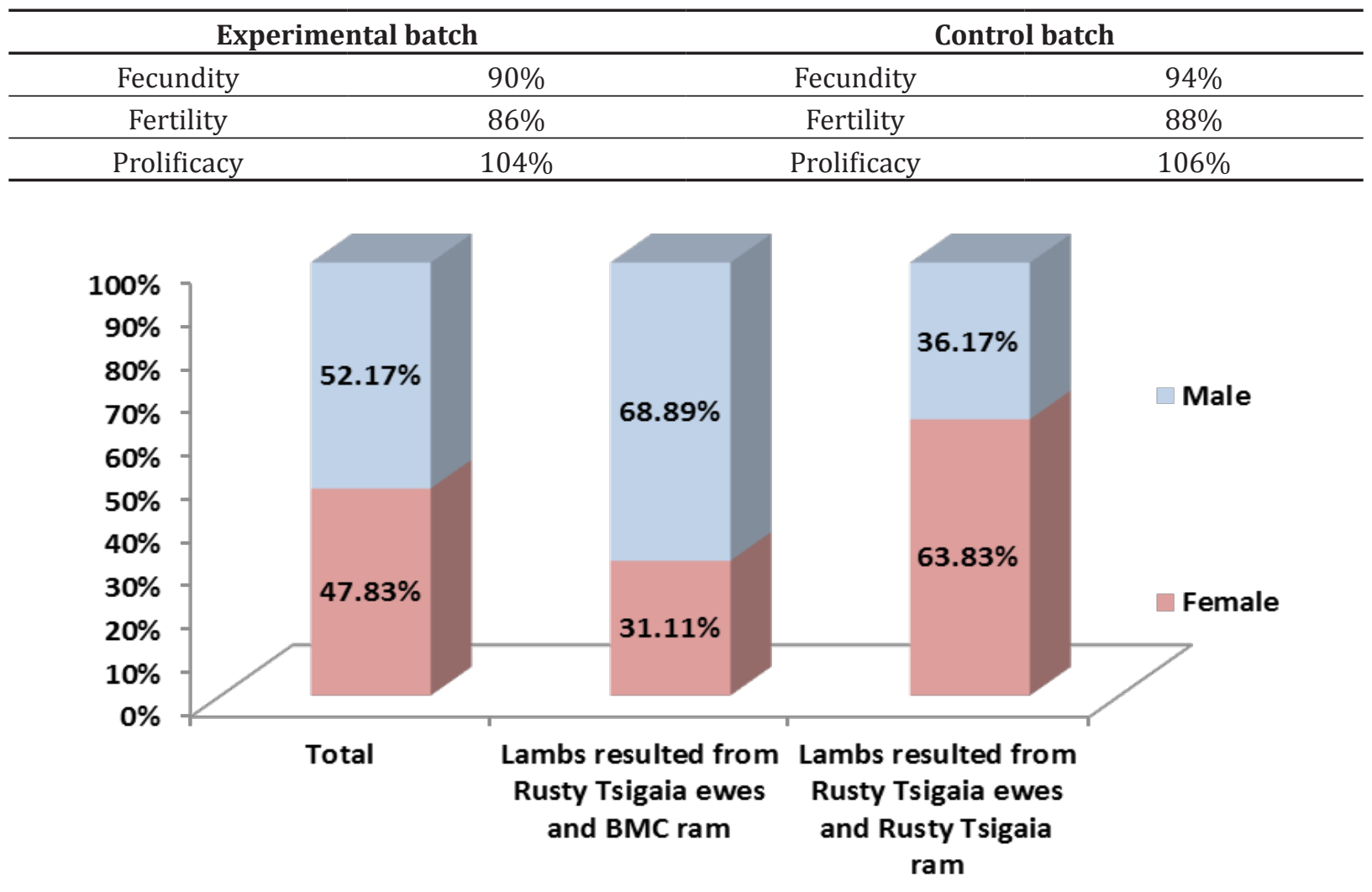

Fig. 1. The share of gender in the two batches of Rusty Tsigaia ewes 
F > F crit, in our case $226.81>3.94$. The averages of the two batches were not equal.

The data recorded after $\mathrm{T}$ test analysis for the statistical differences between the birth weights of the control and experimental batches are presented in Tab. 2.

The $\mathrm{T}$ test applied to compare the statistical differences between the averages of the two batches, according to which if $\mathrm{t}$ Sat $<\mathrm{t}$ Critical two tail or $\mathrm{t}$ Stat $>\mathrm{t}$ Critical two tail, allows to reject the null hypothesis $\left(\mathrm{H}_{\mathrm{o}}\right)$. In our case: - $1.991<$ $14.502>1.991$. We reject $\mathrm{H}_{0}$ and accept $\mathrm{H}_{1}$. There are statistical differences between the averages weights of the birth lambs of the two batches, at $\mathrm{p}=0.05$.

The research that we conducted is an original study, being the first study regarding the crossing between Rusty Tsigaia breed and Blanc du Massif
Central breed. Being a pilot study, the results presented represent the current research stage. In order to accomplish a more larger and reliable data base for the reproductive parameters resulted from the crossing of Rusty Tsigaia pure breed ewes and Blanc du Massif Central ram, further research is necessary.

The research found in the literature concerning the crossing of Tsigaia breed (Pascal and Nechifor, 2014) refer to another variety of Tsigaia breed (not the Rusty Tsigaia variety from our study) and the breed of the paternal line chosen is also different (they used Suffolk breed as paternal line, not Blanc du Massif Central). More than that, the research of the same authors was conducted on the evolution of the lamb's body weight during the fattening process, not on the lamb's weight at birth.

Tab. 2. Anova test analysis for birth weight of the lambs born in the two batches

\begin{tabular}{|c|c|c|c|c|c|c|}
\hline Anova: Single Factor & & & & & & \\
\hline \multicolumn{7}{|l|}{ SUMMARY } \\
\hline Groups & Count & Sum & Average & Variance & & \\
\hline Column 1 & 44 & 229.5 & 5.215909 & 0.347415 & & \\
\hline Column 2 & 46 & 165.3 & 3.593478 & 0.173957 & & \\
\hline \multicolumn{7}{|l|}{ ANOVA } \\
\hline Source of Variation & SS & $d f$ & $M S$ & $F$ & $P$-value & F crit \\
\hline Between Groups & 59.19709 & 1 & 59.19709 & 228.8121 & $3.31 \mathrm{E}-26$ & 3.949321 \\
\hline Within Groups & 22.76691 & 88 & 0.258715 & & & \\
\hline Total & 81.964 & 89 & & & & \\
\hline
\end{tabular}

Tab. 3. T test analysis for the average birth weight in the two batches

\begin{tabular}{|l|r|r|}
\hline \multicolumn{3}{|l|}{ t-Test: Two-Sample Assuming Unequal Variances } \\
\hline & Variable 1 & Variable 2 \\
\hline Mean & 5.188888889 & 3.60212766 \\
\hline Variance & 0.372373737 & 0.173691027 \\
\hline Observations & 45 & 47 \\
\hline Hypothesized Mean Difference & 0 & \\
\hline df & 77 & \\
\hline t Stat & 14.50290388 & \\
\hline $\mathrm{P}(\mathrm{T}<=\mathrm{t})$ one-tail & $5.05805 \mathrm{E}-24$ & \\
\hline t Critical one-tail & 1.664884538 & \\
\hline $\mathrm{P}(\mathrm{T}<=\mathrm{t})$ two-tail & $1.01161 \mathrm{E}-23$ & \\
\hline $\mathrm{t}$ Critical two-tail & 1.991254363 & \\
\hline & & \\
\hline
\end{tabular}




\section{CONCLUSION}

The average weight of the lambs from the experimental batch (Rusty Tsigaia ewes X Blanc du Massif Central ram) was 5,2159 $\pm 0,347 \mathrm{Kg}$, and for the control batch the average was 3,5934 $\pm 0,1739$ $\mathrm{Kg}$.

The study showed that there are statistical differences between averages of the birth weights in the two batches, at a $p=0.05$, confirming the $\mathrm{H}_{1}$ hypothesis (there are statistical differences between birth weights of the lambs in the two batches).

Further research is necessary to evaluate the rate of male lambs resulted between Rusty Tsigaia ewes and Blanc du Massif Central rams.

The high fertility rate, more than $85 \%$, fecundity $90 \%$ and prolificacy $104 \%$, that we obtained on the experimental batch, similar with the control batch (purebred Rusty Tsigaia) sustains the use of the rams from Blanc du Massif Central breed to improve the weight of the Rusty Tsigaia lambs.

Acknowledgements. This work has benefited from financial support through the PN-II-PTPCCA-2013-4-1239 project, No: 152/01.07.2014, "Obtaining the Romanian meat lamb - OVICARO".

\section{REFERENCES}

1. Băcilă V, Rosu I, Sonea C Gigi, Băcilă A (2014). Research On Production Performance Of Crossbred Ewes Produced From The Crossing With Rams Of The Breed Turcana German Black Head Influence On The Economic Efficiency Of Farm, Scientific Papers. Series D. Animal Science. Vol. LVII

2. David LT (2006). Useable Crossbreeding Systems for Small and Large Sheep Flocks
3. Noakes DE, Parkinson T J, England GCW (2009). Veterinary reproduction and Obstetrics, Ninth Edition, Saunders Elsevier, pag. 708, 709, 716

4. Ptaszynska M ( 2009). 10th edition of Compendium of animal reproduction, Publisher Intervet International bv, ISBN 90-801886-6-2

5. FAO STATISTICAL YEARBOOK (2014) Europe and Central Asia Food and Agriculture, Food and Agriculture Organization of the United Nations Regional Office for Europe and Central Asia Budapest, E-ISBN 978-92-5108168-6

6. Groza IS (2006). Ginecologie, andrologie şi obstetrică veterinară - compendiu, Ed. Academiei Române, București

7. Haresign W (1992). Manipulation of reproduction in sheep, J. Reprod. Fertil, Suppl 45: 127-139.

8. O'Callaghan D (1999). A Practical Approach to the Management of Reproductive Seasonality in Sheep, Reprod Dom h i m 34, Blackwell Wissenschafts-Verlag, Berlin ISSN 0936-6768.

9. Rosa HJD, Bryant MJ ( 2003). Seasonality of reproduction in sheep, Review Small Rum Res, 48: 155-171.

10. Pascal C, Gilca I., Ivancia M, Padeanu I, Costica C, Plesca V (2009). Researches regarding the productive capacity of half-breeds $\mathrm{f} 1$ obtained in România from the crossing of Tigaie sheep with Blackhead Pleven breed rams, IVth Balkan Conference of Animal Science, Stara ZagoraBulgaria, Trakia Journal of Sciences, 155-160.

11. Pascal C, Ivancia M, Gilca I, Nacu G, Iftimie N (2009). Carcass quality of $\mathrm{F} 1$ crossings of Ile de France rams with local Romanian sheep, EAAP 2009, 60th Annual Meeting, Barcelona, Spain, Section S 49 b. Sheep and goat feeding and breeding free communications.

12. Pascal C, Nechifor I, 2014, The effect of crossing romanian sheep breeds with rams of meat breeds over the specific indicators of meat production, Lucrări Științifice - Seria Zootehnie, vol. 61(19): 3-10.

13. Padeanu Ioan (2011). Biotehnici de reproducere la ovine. Editura Mirton, Timisoara 